\title{
EFEKTIVITAS PENEGAKAN HUKUM TINDAK PIDANA PENGHIMPUNAN DANA MASYARAKAT SECARA ILEGAL DENGAN MODUS INVESTASI DI KOTA TERNATE
}

Tri Syafari, Basto Daeng Robo

Fakultas Hukum Universitas Khairun, email: trisyaf69@gmail.com

ABSTRAK. Banyak masyarakat Kota Ternate menjadi korban tindak pidana penghimpunan dana masyarakat secara ilegal dengan modus investasi disebabkan oleh berbagai faktor seperti faktor ekonomi dimana masyarakat ingin mendapatkan keuntungan yang berlipat tanpa memikirkan akibat yang akan terjadi dikemudian hari, faktor lingkungan dimana masyarakat hanya melihat para nasabah lain disekitar mereka adalah orang-orang yang memiliki strata pekerjaan dan pendidikan yang baik sehingga masyaraat lainnya ikut yakin dengan kegiatan penghimpunan dana ilegal tersebut dan faktor penerapan hukum terhadap pelaku yang selama ini belum maksimal dan belum dapat memberikan efek jera bari para pelaku lainnya dengan beranggapa bahwa jika ia melakukan tindak pidana tersebut hanya dihukum beberapa tahun dan setelah bebas masih dapat menikmati hasil dari kejahatannya. Disisi lain penegakan hukum tindak pidana penghimpunan dana masyarakat secara ilegal dengan modus investasi di Kota Ternate belum bejalan secara efektif. hal mana pada proses penyidikan masih terdapat banyak pelaku lain yang belum di proses hingga saat ini, selain itu pada tahap penuntutan dan putusan pengadilan, nampak jelas belaum adanya keseriusan oleh para penuntut umum maupun hakim untuk menerapkan hukuman maksimal bagi para pelaku agar dapat meberikan rasa keadilan bagi para nasabah yang menjadi korban serta dapat menjadi pelajaran bagi pelaku lain sehingga takut dan jera untuk melakukan tindak pidana penghimpunan dana masyarakat secara ilegal dengan modus investasi.

Kata kunci : Efektivitas, Penegakan Hukum, Tindak Pidana Penghimpunan Dana Masyarakat.

ABSTRACT. Many Ternate City people are victims of the crime of collecting public funds illegally with an investment mode caused by various factors such as economic factors where people want to get multiple benefits without thinking about the consequences that will occur in the future, environmental factors where the community only sees other customers around them are people who have good employment and education strata so that other community members are convinced of the illegal fundraising activities and the application of the law against the perpetrators which has not been maximized and cannot provide a deterrent effect for other actors by assuming that if they do the crime was only sentenced to a few years and after being released can still enjoy the results of the crime. On the other hand, the law enforcement of criminal acts of collecting public funds illegally with investment mode in Ternate City has not yet run effectively. where in the investigation process there are still many other perpetrators who have not been processed to date, other than that at the stage of prosecution and court decisions, it seems clear that there is serious seriousness by the public prosecutors and judges to apply the maximum sentence for the perpetrators to give a sense of justice for clients who are victims and can be a lesson for other actors so that they are afraid and deterrent from committing the crime of collecting public funds illegally with the investment mode.

Keywords: Effectiveness, Law Enforcement, Criminal Actions of Community Fund Collection.

\section{Pendahuluan}

Kegiatan penghimpunan dana bisa juga dikatakan sebagai proses pencarian sumber dana dana bank. ${ }^{1}$ Lembaga keuangan bank merupakan lembaga keuangan yang memberikan jasa keuangan yang paling lengkap. Lembaga keuangan non bank adalah sektor-sektor yang berhubungan dengan pembiayaan pembangunan berupa pemberian kredit jangka menengah atau jangka panjang juga dapat berupa penyertaan modal dan usaha yang ditujukan untuk memenuhi kebutuhan masyarakat. ${ }^{2}$ Dalam kegiatan investasi yang dilakukan oleh masyarakat terdapat beberapa badan usaha yang memfasilitasi masyarakat dalam melakukan kegiatan investasi, pendirian suatu badan usaha yang mempunyai wewenang untuk melakukan penghimpunan dana tersebut harus mendapat izin dari otoritas yang berwenang. Dalam kenyataannya, banyak badan usaha yang bergerak dalam penghimpunan dana yang tidak memiliki izin yang resmi dari otoritas yang berwenang untuk mengeluarkannya. Hal ini menyebabkan penghimpunan dana yang dilakukan oleh badan usaha tersebut menjadi ilegal. ${ }^{3}$

\footnotetext{
${ }^{1}$ Kasmir, Bank dan Lembaga Keuangan lainnya, Jakarta, PT.Raja Grafindo Persada,2011, hlm. 61.

${ }^{2}$ Ibid, hlm 1.

http://sikapiuangmu.ojk.go.id/id/article/128, diakses tanggal 18 Maret 2019
}

Penghimpunan dana masyarakat yang dilakukan oleh badan usaha harus memiliki izin dari otoritas yang berwenang terlebh dahulu, diantaranya adalah pimpinan Bank Indonesia sebagaimana tertuang dalam pasal 16 ayat (1) Undang-Undang Nomor 10 tahun 1998 tentang Perbankan yang menyebutkan :'Setiap pihak yang melakukan kegiatan menghimpun dana dari masyarakat dalam bentuk simpanan wajib terlebih dahulu memperoleh izin usaha sebagai Bank Umum atau Bank Perkreditan Rakyat dari Pimpinan Bank Indonesia, kecuali apabila kegiatan menghimpun dana dari masyarakat dimaksud diatur dengan Undang-undang tersendiri."

Dalam pasal diatas terdapat dua jenis yang dapat memiliki wewenang untuk melakukan kegiatan menghimpun dana dari masyarakat yaitu bank umum dan bank perkreditan rakyat, Pasal 21 ayat (1) Undang-Undang Nomor 10 tahun 1998 tentang perbankan menyebutkan bentuk hukum dari kedua bank tersebut yaitu bentuk hukum suatu bank umum dapat berupa perseroan terbatas, koperasi dan perusahaan daerah. Bentuk hukum dari suatu bank perkreditan rakyat berupa perusahaan daerah, koperasi perseroan terbatas dan bentuk lain bentuk lain yang ditetapkan dengan peraturan pemerintah.

Salah satu modus yang berkembang adalah upaya menghimpun dana guna

http://ejournal.unkhair.ac.id/index.php/humano 397 
Jurnal Penelitian Humano, Vol. 10 No. 1 Edisi Juni 2019

mendapatkan keuntungan dengan melalui investasi atau penanaman modal yang diimingi dengan keuntungan yang sangat menggiurkan atau dengan bunga di luar batas kewajaran. Selain itu untuk meyakinkan masyarakat, perusahaan tersebut berupaya untuk memperlihatkan bahwa investasi yang dilakukan adalah ril dan bergerak di berbagai sektor usaha seperti perdagangan, jasa, pertanian, peternakan, sekuritas, valuta asing dan emas. Namun dalam realitanya, usaha tersebut tidak lain dari hanyalah memutarkan dana yang sudah dihimpun dari masyarakat atau investor untuk membayarkan keuntungan dan cicilan uang yang sudah diterima. Jadi usaha tersebut sangat tergantung kepada akumulasi dana yang masuk melalui investor yang baru bukan melalui keuntungan yang diperoleh kegiatan usaha usaha.

Kegiatan investasi tersebut menawarkan keuntungan dari hasil kegiatan usaha yang tetap dan tinggi sehingga masyarakat tanpa pikir panjang menginvestasikan uangnya sehingga menimbulkan tindak pidana. Dalam bagian ini dikemukakan mengenai hal-hal yang berkatitan dengan tindak pidana di bidang perbankan sebagai salah satu bentuk dari tindak pidana di bidang ekonomi. ${ }^{4}$

Dalam hal perlindungan hukum bagi masyarakat atas tindak pidana penghimpunan dana secara ilegal, Undang-Undang Nomor 10 Tahun 1998 tentang Perbankan telah memberikan pengaturan yang lengkap dan tentang mekanisme bagaimana proses mekanisme proses penghimpunan dana sampai ketentuan pidana apabila melakukan tindak pidana penghimpunan dana mayarakat, sehingga dalam penerapan hukum terhadap pelaku tindak pidana dibidang perbankan, undang-undang ini dapat secara penuh diterapkan sesuai dengan Pasal 63 ayat (2) Kitab Undang-Undang Hukum Pidana yaitu : "jika suatu perbuatan masuk dalam suatu perbuatan umum, diatur pula dalam aturan pidana yang khusus, maka hanya yang khusus itulah yang diterapkan.

Awal tahun 2018 Kota Ternate dihebohkan setelah munculnya permasalahan yang terjadi pada CV. Ubay Jaya yang bergerak di bidang investasi ini diserbu para nasabah lantaran keterlambatan pembayaran uang investasi dari para nasabah. Permasalahan CV. Ubay Jaya sendiri telah menyeret beberapa nama yang dianggap betanggungjawab seperti Astrid Fitrianti Pakaya, Hastuti Munir, Maswita, Sugiarti R. Hataul, Siti Rahayu Falila dan Dewi Irawati Pakaya. Dari keenam orang yang dianggap bertanggungjawab tersebut tiga diantaranya telah ditetapkan sebagai tersangka tindak pidana penghimpunan dana masyarakat secara ilegal, dan bahkan Astrid Fitrianti Pakaya telah menjalani

4 Hermansyah, Hukum Perbankan Nasional Indonesia, Jakarta,Kencana Prenada Media Group, 2005, hlm 159. persidangan serta telah dijatuhkan vonis oleh Pengadilan Negeri Ternate.

Ratusan orang yang tertipu investasi bodong CV. Ubay Jaya nyatanya tak menjadi pelajaran berharga bagi warga lainnya. Pertengahan Tahun 2018 Sejumlah warga kembali tertipu investasi bodong dengan modus balik modal. Saat ini, dua pengelola investasi atas nama Rahayu dan Amelia telah ditetapkan tersangka oleh pihak kepolisian. Rahayu dan Amelia yang tercatat sebagai pegawai Kantor Samsat Kota Ternate itu mengiming-imingi para nasabah dengan pengembalian modal plus bunga 100 persen. Tak tanggung-tanggung, uang dua kali lipat itu bisa diterima dalam jangka waktu 20 hari saja. Namun setelah penetapan tersangka terhadap kedua pelaku tersebut hingga saat ini belum ada kejelasan perkembangan kasusnya di Kepolisian. Masih dipertengahan tahun 2018, ketika kasus CV. Ubay Jaya masih dalam tahap Persidangan, korban investasi bodong kembali mewarnai Kota Ternate. Kali ini Dedi selaku Bos CV. Arfi Group yang kemudian ditetapkan sebagai tersangka oleh pihak Kepolisian. Saat ini Dedi selaku Bos CV. Arfi Group tengah menjalani persidangan di Pengadilan Negeri Ternate. Kemudian diakhir tahun 2018, yang tidak kalah menggemparkan warga Kota Ternate adalah PT Karapoto Teknologi Finansial Ternate, Maluku Utara, dengan pimpinan perusahaan adalah Fitri Puspita Hapsari Doa, yang bertempat di Kelurahan Dufa-Dufa, Kota Ternate. Hingga saat ini belum ada kejelasan status hukum terhadap pimpinan PT Karapoto Teknologi Finansial, oleh karena sejauh ini masyarakat yang menjadi korban masih dijanjikan pengembalian modal oleh pihak perusahaan. Hal tersebut kemudian menyebabkan adanya reaksi nasabah yang dirugikan untuk menuntut pengembalian modal investasi.

Dari berbagai kasus yang terjadi di Kota Ternate, telihat bahwa dengan mudahnya masyarakat tergiur untuk ikut dalam investasi yang tidak memiliki izin atau investasi ilegal hanya dengan iming-iming akan mendapatkan keuntungan yang besar dari modal yang di investasikan, tanpa mempedulikan apakan perusahaan tersebut telah memiliki izin dari otoritas yang berwenang. Fenomena maraknya investasi ilegal yang terjadi di Kota Ternate ini seharusnya menjadi perhatian khusus bagi aparat penegak hukum dalam menindaklanjuti adanya tindak pidana yang meneyebabkan masyarakat menjadi korban dari tindak pidan tersebut. Seharusnya aparat penegak hukum dapat bergerak cepat untuk melakukan law enforcment guna mencegah semakin banyaknya masyarakat yang menjadi korban. Oleh karena sudah sangat jelas kegiatan penghimpunan dana masyarakat secara ilegal dengan modus investasi tersebut telah melanggar ketentuan Undang-Undang Nomor 10 tahun 1998 tentang Perbankan. 
Jurnal Penelitian Humano, Vol. 10 No. 1 Edisi Juni 2019

Namun dengan kenyataannya, hingga saat ini belum semua kasus invesatsi ilegal diproses oleh aparat penegak hukum hingga ke persidangan, masih terdapat beberapa kasus yang hingga saat ini belum jelas sampai dimana penangnannya. Seharusnya kasus tindak pidana penghimpunan dana masyarakat secara ilegal dengan modus investasi seperti ini harusnya mendapatkan perhatian khusus dari parat penegaka hukum dengan mengambil langkahlangkah cepat dalam memproses tindak pidana tersebut oleh karena yang menjadi korban adalah masyarakat banyak yang suatu waktu dapat menimbulkan gejolak, sehingga terjadi kegaduhan ditengah-tengah masyarkat. Kondisi tersebut dapat menyebabkan dampak negatif terhadap pertumbuhan ekonomi negara, dapat menyebabkan kerugian yang sangat besar dan menyebabkan hilangnya kepercayaan masyarakat untuk menginvestasikan kekayaanya kepada lembaga investasi yang legal. Karena hampir semua perusahaan investasi ilegal memberi iming-iming keuntungan bagi peserta atau investor dalam jumlah yang sangat besar dan seketika.

Berdasarkan uraian tersebut diatas, maka objek kajian pada penelitian ini dirumuskan sebagai berikut: Pertama, Faktor-faktor apa yang menyebabkan banyak masyarakat Kota Ternate menjadi korban Tindak Pidana Penghimpunan Dana Masyarakat Secara Ilegal Dengan Modus Investasi? Kedua, Bagaimana efektivitas penegakan hukum Tindak Pidana Penghimpunan Dana Masyarakat Secara Ilegal Dengan Modus Investasi di Kota Ternate?

\section{Kajian Kepustakaan}

Penghimpunan dana bisa juga dikatakan sebagai proses pencarian sumber dana bank. Lembaga Perbankan adalah lembaga keuangan yang menjadi perantara antara pihak yang mempunyai kelebihan dana (Surplus of funds) dengan pihak yang membutuhkan (Lack of Funds). Menurut Thomas Suyanto secara garis besar sumber dana bagi sebuah bank dibagi menjadi tiga macam, yaitu ${ }^{5}$ :

a) Dana yang bersumber dari bank sendiri;

b) Dana yang bersumber dari masyarakat luas;

c) Dana yang berasa dari lembaga keuangan, baik berbentuk bank maupun bukan bank. Bentuk usaha menghimpun dana masyarakat hadir untuk menyalurkan kepada masyarakat dana-dana yang dikelola, dalam bentuk kredit dan/atau bentuk-bentuk lainya dalam rangka meningkatkan taraf hidup masyarakat. Sesuai dengan pasal 6 UndangUndang No 10 Tahun 1998 tentang Perbankan, maka penghimpunan dana bentuk bank, meliputi: menghimpun dana dari masyarakat dalam bentuk simpanan berupa giro, deposito berjangka, sertifikat berjangka, tabungan, dan atau bentuk lainya yang dipersamakan dengan itu. ${ }^{6}$

Kebutuhan akan dana yang meningkat khususnya untuk kegiatan usaha atau bisnis, usaha penghimpunan dana tidak lagi hanya melakukan penghimpunan dana dengan cara giro, deposito, sertifikat deposito, maupun tabungan, melainkan dengan investasi dengan menghimpun dana dari masyarakat dan menjanjika keuntungan yang dilakukan oleh perorangan ataupun badan hukum. Investasi pada umumnya terutama dalam investasi langsung masyarakat yang menjadi konsumen akan menjadi milik usaha dan akan memperoleh hak untuk mendapatkan keuntungan. Keuntungan didapat jika perusahaan memperoleh keuntungan, sebaliknya jika perusahaan merugi, maka masyarakat sebagai konsumen akan juga merugi bahkan dana yang disimpan menjadi hilang. ${ }^{7}$ Salah satu bentuk penghimpunan dana yang dilakukan terhadap masyarakat adalah dengan tujuan Investasi, Investasi yaitu mengeluarkan sejumlah uang atau menyimpan uang pada sesuatu dengan harapa suatu saat akan mendapatkan keuntungan financial, berikut ini adalah pengertian investasi menurut para ahli :

a) Pengertian investasi menurut Kamus Besar Bahasa Indonesia $(\mathrm{KBBI})^{8}$ adalah, penanaman uang atau modal untuk satu atau lebih aktiva yang dimilikidan biasanya berjangka waktu lama dengan harapan mendapatkan keuntungan di masa-masa yang akan datang

b) Pengertian investasi menurut Haming dan Basalamah:" "Investasi merupakan pengeluaran pada saat seakarang untuk membeli aktiva riil (tanah, rumah, mobil, dsb) atau aktiva keuangan dangan tujuan untuk mendapatkan penghasilan yang lebih besar dimasa yang akan datang

c) Pengertian investasi menurut Sunariyah: ${ }^{10}$ “ Investasi adalah penanaman modal untuk satu atau lebih aktiva yang dimiliki dan biasanya berjangka waktu lama dengan harapan mendapatkan keuntungan di masa-masa yang akan datang.

Tujuan dari investasi adalah mendapatkan suatu tingkat pendapatan, yang diharapkan di masa yang akan datang, tetapi dengan mengorbankan kekayaan saat ini. Pada dasarnya tujuan ornag melakukan investasi adalah untuk

\footnotetext{
6 Wijdinarto, Hukum dan Ketentuan Perbankan Di Indonesia, PT. Pustaka Utama Grafiti, Jakarta, Edisi II Cet1, 2003 hlm 62.

7 Arsil, Menjerat Investasi Bodong dengan Tindak Pidana Penghimpunan Dana Masyarakat Secara Ilegal Dengan Modus Investasi, Lembaga Kajian \& Advokasi untuk Indepedensi Peradilan, Jakarta, 2014 hlm, 1

${ }^{8} \mathrm{http} ; / / \mathrm{kbbi}$.web/investasi diakses tanggal 18 Maret 2019 http://id.scribd.com/doc/84916732/Pengertian-investasi diakses tanggal 18 Maret 2019
}

http://pengertianbahasa.blogspot.com/2013/02/pengertianinvestasi.html diakses tanggal 18 Maret 2019

http://ejournal.unkhair.ac.id/index.php/humano 399 
Jurnal Penelitian Humano, Vol. 10 No. 1 Edisi Juni 2019 menghasilkan sejumlah uang. Tandelilin menyatakan ada beberapa alasan mengapa seseorang melakukan investasi, antara lain : ${ }^{11}$

a) Untuk mendapatkan kehidupan yang lebih layak di masa depan. Seseorang yang bijaksana akan berpikir bagaimana meningkatkan taraf hidupnya dari waktu ke waktu atau setidaknya berusaha bagaimana mempertahankan tingkat pendapatanya yang ada seakarang agar tidak berkurang di masa yang akan datanag.

b) Mengurangi resiko inflasi Dalam melakukan investasi dalam pemilikan perusahaan atau obyek lain, seseorang dapat menghindarkan diri dari resiko penurunan nilai kekayaan atau hak miliknya akibat adanya pengaruh inflasi.

Investasi ilegal atau investasi bodong merupakan istilah yang sering dikenal dalam dunia investasi. Iming-iming imbal hasil yang ditawarkan ditambah bujukan serta kurangnya pemahaman tentang investasi membuat seseorang dengan mudah berinvestasi pada instrumen dan perusahaan investasi yang salah. ${ }^{12}$ Perusahaan atau pihak yang melakukan penawaran investasi ilegal hampir sebagian besar bukan berasal dari Lembaga Jasa Keuangan (LJK) sehingga perusahaan tersebut tidak terdaftar di OJK. Fakta membuktikan banyak orang terjebak ingin kaya mendadak tanpa kerja keras. Kesempatan ini digunakan oleh pihak tidak bertanggung jawab dengan melakukan penipuan berkedok investasi. Perusahaan investasi ilegal menyadari karakter investor jika para investor awal mendapatkan return sesuai yang dijanjikan, mereka cenderung menginvestasikan kembali dari uang tersebut. Bahkan kemungkinan mengajak keluarga, teman, atau relasi mereka untuk berinvestasi. ${ }^{13}$

\section{Metode Penelitian}

Penelitian ini merupakan penelitian hukum empiris yang meneliti Efektivitas Penegakan Hukum Tindak Pidana Penghimpunan Dana Masyarakat Secara Ilegal Dengan Modus Investasi di Kota Ternate. Adapun populasi pada penelitian ini adalah semua pihak yang terkait dengan proses penegakan hukum pada tindak pidana Penghimpunan Dana Masyarakat Secara Ilegal Dengan Modus Investasi. Sedangkan sampel pada penelitian ini ditetapkan berdasarkan pemilihan dengan teknik Sampel Mudah (Convenience Sampling) dimana teknik penentuan sampel berdasarkan kebetulan saja. Jadi anggota populasi yang ditemui peneliti dan bersedia menjadi responden yang akan dijadikan sampel. Adapun pihak dijadikan responden adalah: Pihak Pengadilan Negeri Ternate; Pihak Kejaksaan

\footnotetext{
11 http://jurnsl-dfm.blogdpot.com/3009/07/keputusanberinvestasi-tujuan-dasar-dan.html diakses tanggal 18 Maret 2019

12 Budi Untung, Buku Cerdas Investasi (Yogyakarta: C.V Andi Offset, 2011) hlm. 101.

${ }^{13}$ Ibid., hlm. 107
}

Tinggi Maluku Utara; Pihak Kepolisian Daerah Maluku Utara; Para pelaku tindak pidana Penghimpunan Dana Masyarakat Secara Ilegal Dengan Modus Investasi; dan Masyarakat yang merupakan korban tindak pidana Tindak Pidana Penghimpunan Dana Masyarakat Secara Ilegal Dengan Modus Investasi.

Pengumpulan data digunakan metode kepustakaan dari berbagai putusan pada kasus yang terjadi di Kota Ternate, Berita Acara Pemeriksaan ditingkat Penyidikan, Berita Acara Penuntutan, jurnal ilmiah, buku-buku, serta tulisan-tulisan lainnya yang berkaitan dengan masalah yang di bahas dalam penelitian ini. Kemudian metode lapangan (Field Methode), peneliti mengambil data dengan cara : Observasi, yaitu mengadakan peninjauan langsung ke kantor Polda Maluku Utara, Kejaksaan Tinggi Maluku Utara, Pengadilan Negeri Ternate serta masyarakat Kota Ternate yang menjadi korban Tindak Pidana Penghimpunan Dana Masyarakat Secara Ilegal Dengan Modus Investasi, guna memperoleh data sebagai bahan penulisan dan Interview, dalam hal ini melakukan tanya jawab langsung terhadap responden untuk memperoleh informasi dan data yang akan menjawab berbagai permasalahan.

Data Primer, yaitu data yang diperoleh atau bersumber melalui wawancara langsung dengan narasumber terkait yakni para pihak sebagai yang disebutkan dalam populasi dan sampel. Data Sekunder, yaitu data yang diperoleh dari buku-buku serta tulisan-tulisan yang berkaitan dengan penelitian ini. Data yang telah terkumpul, baik primer maupun sekunder akan dianalisis secara kualitatif.

\section{Pembahasan}

Faktor-Faktor Yang Menyebabkan Banyak Masyarakat Kota Ternate Menjadi Korban

\section{a. Faktor Ekonomi}

Kemajuan perekonomian Indonesia, khususnya kemajuan dalam bidang perbankan berkembang dengan sangat pesat, selain berdampak positif, tentu ada pula dampak negatifnya berupa timbulnya masalah-masalah baru yang belum pernah terjadi sebelumnya. Dampak negatif tersebut timbul sebagai perkembangan dunia perbankan itu sendiri, maupun karena ada oknum-oknum yang memanfaatkan celah-celah atas industri perbankan. Korban kejahatan perbankan tidak dapat dilepaskan dari bentuk-bentuk kejahatan tindak pidana yang ada dan seringkali para korban tersebut adalah para pihak yang mempunyai interaksi langsung dengan produk-produk perbankan yang ada. Para pihak yang menjadi korban ialah para masyarakat pengguna jasa produk-produk bank, seperti nasabah deposan, penabung, maupun pihak bank itu sendiri sebagai penyelenggara perbankan dan juga bahkan pemerintah ataupun negara. Dengan pertumbuhan 
Jurnal Penelitian Humano, Vol. 10 No. 1 Edisi Juni 2019

dan perkembangan perbankan itu sendiri, dimana semakin cepat dan semaraknya dunia perbankan maka secara bersamaan itu pula kejahatan di bidang perbankan juga meningkat, yang berarti semakin banyak dan beraneka ragam modus operandi kejahatan tersendiri, sehingga para korban semakin luas dan bersifat abstrak dan sulit ditelusuri.

Pada kasus CV. Ubay Jaya, CV. Arfi Group dan PT. Karapoto Finansial Teknologi, korban mempunyai peranan tersendiri dalam kejahatan yang terjadi. Dalam kasus-kasus tertentu kejahatan bidang perbankan seperti kasus menghimpun dana masyarakat secara ilegal dengan modus investasi. Peranan korban sangat besar. Pada umumnya korban mengharapkan reward (bunga, deviden, pembagian hasil keuntungan) yang sebenarnya tidak masuk akal sehat. Namun karena adanya keinginan untuk mendapatkan keuntungan dari korban, dan terlena oleh penampilan sesaat para pengelola perusahaan.

Kejahatan dengan modus investasi ini terjadi dikarenakan faktor-faktor sosial terhadap diri pelaku mapun yang terdapat pada diri korban itu sendiri. Faktor-faktor yang paling dominan hingga terwujudkan kejahatan ini adalah faktor ekonomi, sebab dengan kerasnya kebutuhan hidup serta gaya hidup yang tinggi menyebabkan orang tidak lagi melihat resiko serta dampak yang akan timbul dalam melakukan suatu perbuatan, contoh kejahatan dengan modus investasi, dengan diiming-iming keuntungan yang besar, mengakibatkan para korban tanpa memikirkan resiko langsung menyerahkan uangnya dengan harapan keuntungan yang di dapat dikemudian hari, tanpa mengetahui diapakan uang-uang tersebut hingga bisa kembali dengan keuntungan yang besar. Terjadinya kejahatan bermodus investasi ini adalah faktor ekonomi, para pelaku serta korban yang hidup dengan berbagai keterbatasan, terdorong dengan keinginan untuk segera menjadi kaya tanpa melalui proses yang baik mengakibatkan cara-cara melanggar hukum pun dilakukan untuk memenuhi hasrat atau keinginan itu sendiri. ${ }^{14}$

Dorongan ekonomi serta janji atau harapan yang disampaikan oleh pelaku, membuat para korban tanpa berpikir panjang langsung menyerahkan uang dengan nominal yang bervariasi, dengan bunga pengembalian sebesar $100 \%$ sampai dengan $300 \%$ per sekali transaksi dengan tempo selama 8 sampai 20 hari, kesepakatan bunga dengan nilai $100 \%$ sampai $300 \%$ tersebut diberikan oleh pelaku sebab pelaku dalam sehari dapat melakukan transaksi puluhan bahkan ratusan kali dengan bermain game online, judi online dan perdagangan komoditi ( trading /

\footnotetext{
14 Wawancara dengan Ekawati, Selaku Korban tindak pidana penghimpunan dana masyarakat secara ilegal dengan modus investasi di Kelurahan Dufa-Dufa pada Hari Rabu Tanggal 4 September 2019
}

Forex ) yang keuntungannya bervariasi antara $50 \%$ sampai $75 \%$ tergantung keuntungan yang diberikan oleh situs-situs trading online ( Olympic Trade, UBS FX Option trading, GK Invest ). ${ }^{15}$

Praktek inilah yang rata-rata digunakan oleh pelaku kejahatan penipuan investasi dalam mengelola uang nasabah yang disetorkan kepada mereka, bahwa praktek yang dilakukan ini merupakan praktek yang dilarang oleh undangundang. Namun desakan ekonomi dan imingiming untuk menjadi kaya raya tanpa melalui proses yang baik dan benar, mengakibatkan para pelaku tidak lagi memikirikan resiko atau ancaman hukuman terhadap praktek atau kegiatan usaha yang dijalankan tersebut.

\section{b. Faktor Lingkungan}

Secara sadar mereka menjadi nasabah untuk selanjutnya menjadi korban kejahatan tersebut, para nasabah dan calon nasabah sudah sangat percaya kepada CV. Ubay Jaya, CV. Arfi Group dan PT. Karapoto Finansial Teknologi untuk menginvestasikan uang mereka, karena para korban menyakini bahwa tempat mereka menyimpan uang adalah tempat yang legal disebabkan karena faktor lingkungan dimana mereka melihat para perjabat Aparatur Sipil Negara, anggota TNI dan POLRI yang menyimpan uangnya di CV. Ubay Jaya, CV. Arfi Group dan PT. Karapoto Finansial Teknologi, karena hal tersebutlah para nasabah yang terdiri dari TNI, POLRI, Aparatur Sipil Negara dan masyarakat biasa percaya pada CV. Ubay Jaya, CV. Arfi Group dan PT. Karapoto Finansial Teknologi dan menginvestsikan uang mereka.

Berdasarkan hasil wawancara dengan Naufal Hasan ${ }^{16}$ yang juga sebagai korban tindak pidana penghimpunan dana masyarakat secara ilegal dengan modus investasi, mengatakan bahwa awalnya ia ragu untuk ikut dalam investasi yang dilakukan oleh Astrid Fitrianti, namun karena melihat orang-orang disekitarnya yang telah lebih dulu menjadi nasabah yang pekerjaannya ada sebagai anggota Polri, Aparatur Sipil Negara, maka akhirnya ia yakin untuk ikut bergabung menginvestasika uanggnya dengan harapan akan mendapatkan keuntungan yang berlipat ganda. Namun apa yang diharapkan tesebut tidak sesuai dengan harapan sesungguhnya setelah Astrid Fitrianti kemudian diproses hukum dan telah dijatuhi hukuman pidana oleh pengadilan sedangkan modal investasinya tidak juga dikembalikan.

Berdasarkan data yang penulis peroleh pada Dirreskrimsus Polda Maluku Utara dan hasil

\footnotetext{
${ }^{15}$ Wawancara dengan Mega Safitri Amra, Selaku Korban tindak pidana penghimpunan dana masyarakat secara ilegal dengan modus investasi di Kelurahan Salero pada Hari Senin Tanggal 2 September 2019

${ }^{16}$ Wawancara dengan Naufal Hasan, Selaku Korban tindak pidana penghimpunan dana masyarakat secara ilegal dengan modus investasi di Kelurahan Kalumata pada Hari Senin Tanggal 2 September 2019
}

http://ejournal.unkhair.ac.id/index.php/humano 401 
Jurnal Penelitian Humano, Vol. 10 No. 1 Edisi Juni 2019 wawancara dengan Edy Sugiharto ${ }^{17}$ yang mengatakan bahwa jenis pekerjaan dan tingkat pendidikan korban juga bervariasi. Hal tersebut sesuai dengan data para korban berdasarkan pada kartu identitas yang telah dikumpulkan oleh penyidik Berikut adalah jenis pekerjaan yang mendominasi korban kejahatan investasi bermodus bank gelap :

a) Aparatur Sipil Negara (ASN) yang terdiri dari Pegawai Negeri dan Honorer

b) Wiraswasta

c) TNI/Polri

d) Ibu Rumah Tangga

e) Karyawan Swasta

f) Buruh, nelayan dan petani

Dengan melihat latar belakang jenis pekerjaan para korban, nampak bahwa para korban ini berasal dari para masyarakat yang memiliki tingkat pendidikan yang cukum memadai serta memiliki penghasilan yang cukup. Artinya para korban ini memiliki kemampuan finansial dalam hal untuk memenuhi kehidupan sehari-hari. Jika kita melihat data yang ada, maka korban kejahatan penipuan bermodus bank gelap ini didominasi oleh para Aparatur Sipil Negara kemudian oleh aparat penegak hukum dalam hal ini anggota TNI/Polri.

Jika melihat jenis pekerjaan dan latar belakang pendidikan para korban maka menurut penulis, peranan korban terhadap kejahatan Penghimpunan dana masyarakart secara ilegal ini sangat signifikan. Sebagai contoh para Aparatur Sipil Negara dan para aparat penegak hukum seperti TNI/Polri seharusnya dapat menyadari lebih awal dan lebih memahami bahwa perbuatan yang dilakukan oleh pelaku adalah merupakan perbuatan yang melanggar hukum karena usaha yang dijalankannya tidak memiliki legalitas berupa ijin dari pihak yang berwenang. Tidak seharusnya para Aparatur Sipil Negara dan aparat penegak hukum ini turut serta menanamkan modalnya pada sebuah perusahaan yang tidak jelas asal usul perijiannya. Sudah sepetutnya aparatus sipil negara dan aparat penegak hukum ini menjadi contoh bagi masyarakat dan dapat melakukan upaya pencegahan kepada masyarakat agar tidak timbul korban seperti saat ini. Namun kenyataannya malah sebaliknya, para aparatur sipil negara dan aparat penegak hukum inilah yang paling mendominasi menjadi korban kejahatan perbankan yang dilakukan oleh pelaku.

c. Faktor Penerapan Hukum

Dalam penerapan Hukum ini, penulis hanya akan menguraikan dari sisi produk hukum atau putusan pengadilan, serta ancaman hukuman terhadap pelaku kejahatan ini. Sebagaimana kita ketahui saat ini terdapat 3 kasus Tindak Pidana Penghimpunan Dana Masyarakat Secara Ilegal

17 Wawancara dengan Edy Sugiharto, Selaku Penyidik/Kasubdit II Fismondev Polda Maluku Utara pada Hari Selasa Tanggal 24 September 2019
Dengan Modus Investasi dengan cara menghimpun dana masyarakat dengan modus investasi di Kota Ternate yang pelakunya telah menjadi terpidana berdasarkan putusan Pengadilan Negeri Ternate. Jika melihat tiga perkara yang telah diputus terdapat perbedaan dan bahkan bisa dibilang terjadi disparitas pemidanaan. Hakim dalam menjatuhkan putusan terlihat tidak konsisten. Hal tersebut nampak dalam putusan Astrid Fitrianti yang jumlah kerugiannya mencapai Rp. 6.618.700.000, dituntut sama dengan Dedi dan Siti Rahmatia Haras yang kerugiannya hanya Rp. 1.186.500.000 yakni 7 (tujuh) Tahun penjara dan denda 10 Milyar rupiah kumudian oleh hakim Astrid Fitrianti diputus bersalah dan dihukum penjara selama 5 (lima) Tahun dan denda 10 milyar rupiah sedangkan Dedi dan Siti Rahmatia Haras divonis 7 (tujuh) tahun dan denda 10 milyar rupiah mengikuti tuntutan penuntut umum. Kemudian untuk Suhseti dituntut 8 (delapan) tahun penjara dan denda 10 milyar rupiah padahal kerugiannya hanya Rp. 1.587.000.000, oleh hakim diputus bersalah dan dihukum Penjara 5 tahun 6 bulan dan denda 10 Milyar. ${ }^{18}$

Dari 3 putusan hukum yang telah disebutkan di atas, ini menjadi tolak ukur terhadap pelaku kejahatan yang lain atau yang saat ini masih menjalankan bisnisnya, bagaimana tidak, dalam kurun waktu 2 atau 3 bulan pelaku dapat menghimpun dana dari masyrakat sejumlah milliaran rupiah, dengan hukuman 5 dan 7 tahun sebagaimana 3 putusan pengadilan di atas, pelaku lebih memilih menjalani putusan dari pada harus mengembalikan dana yang telah berhasil mereka himpun. Para pelaku ini mempunyai komunikasi menyeluruh, yang setiap saat meng-update proses persidangan rekan-rekannya yang lebih dulu perkaranya diajukan ke pengadilan, bagaimana tidak dengan kerugian yang begitu besar dan hukuman yang terkesan berada diangka minimal mengakibatkan para pelaku tidak jera untuk berhenti melakukan kejahatan ini.

Kelemahan inilah yang juga dimanfaatkan pelaku kejahatan penipuan investasi untuk menjalankan bisnisnya, dalam melakukan kejahatan ini, dalam melakukan kegiatan investasi mereka owner selalu melakukan hitung-hitungan, antara resiko dengan keuntungan yang didapat, rata-rata dari hasil penelitian penulis menemukan bahwa kejahatan investasi dengan kerugian dibawah 1 milliar lebih memilih mengembalikan modal nasabah dari pada berhadapan dengan proses hukum, namun kejahatan investasi dengan kerugian diatas 1 milliar lebih memilih di proses secara hukum dari pada mengembalikan dana nasabah yang telah di setor kepada pelaku, contoh dalam kasus CV. Ubay Jaya atas nama Astrid

\footnotetext{
${ }^{18}$ Putusan Pengadilan Negeri Ternate Nomor 184/Pid.B/2018/PN.Tte, Nomor 313/Pid.B/2018/PN.Tte dan Nomor 119/Pid.B/2019/PN.Tte
}

http://ejournal.unkhair.ac.id/index.php/humano 402 
Jurnal Penelitian Humano, Vol. 10 No. 1 Edisi Juni 2019

Fitriyanti yang saat ini telah divonis penjara oleh Pengadilan Negeri Ternate, dimana dalam kasus tersebut kerugian yang dialami oleh oleh salah satu saksi yang bernama Hastuti dari total 795 nasabah dana yang telah menyetor uang kepada saksi dan saksi menyetor kepada pelaku yaitu senilai Rp. 13.548.200.000.- ( tiga belas milliar lima ratus empat puluh delapan juta dua ratus ribu rupian $)^{19}$. Ini merupakan jumlah yang besar dari sebuah kejahatan investasi itu sendiri, sayangnya dari 3 kasus tindak pidana penghimpunan dana masyarakat secara ilegal dengan modus investasi dengan cara menghimpun dana masyarakat dengan modus investasi ini yang telah diputuskan bersalah oleh Pengadilan Negeri Ternate dan telah berkekuatan hukum tetap (Inkrach van gewijct) tidak ada satupun terpidana yang dijerat dengan Undang-undang Pencucian uang, semuanya hanya dijerat dengan Undangundang Perbankan, padahal dengan menerapkan Undang-undang Pencucian Uang adalah sebagai bentuk upaya negara untuk mengejar aset para pelaku kejahatan dimaksud. Padahal dalam kejahatan ini patut diduga ada aset yang diperoleh dari tindak pidana itu sendiri yang disamarkan sehingga seolah-olah harta kekayaan itu diperoleh dengan cara yang sah. Sehingga meskipun pelaku tindak pidana tersebut telah mempertanggungjawabkan perbuatannya namun kerugian korban tidak dapat dipulihkan kembali, korban sama sekali tidak mendapatkan pengembalian uang yang telah diinvestasikan.

Efektivitas Penegakan Hukum Tindak Pidana Penghimpunan Dana Masyarakat Secara Ilegal Dengan Modus Investasi Dengan Modus Investasi Di Kota Ternate.

a. Penyidikan oleh Kepolisian

Proses penyidikan tindak pidana penghipunan dana masyarakat dengan modus investasi yang dilakukan oleh penyidik Polda Maluku Utara baru berhasil menyidik 9 (sembilan) orang pelaku tindak pidana penghimpunan dana masyarakat secara ilegal dengan modus investasi yang telah menghimpun dana secara ilegal dengan modus investasi dan bahkan telah melimpahkan berkas perkaranya kepada Kejaksaan untuk kemudian disidangkan. Dari sembilan orang pelaku tersebut terdiri dari 3 perusahaan berkedok investasi, dengan masingmasing kerugian yang diakibatkannya mencapai milyaran rupiah. Sedangkan berdasarkan hasil telaah dokumen baik putusan pengadilan maupun surat dakwaan Penuntut Umum ternyata masih terdapat pelaku lain yang secara bersama-sama dengan kesembilan pelaku tersebut. Namun dari data penyidikan yang dilakukan oleh Polda Maluku Utara masih terdapat beberapa pelaku yang bersama-sama dengan pelaku Fitri Puspita Hapsari pun didakwa bersama-sama dengan

19 Putusan Pengadilan Negeri Ternate Nomor 184/Pid.B/2019/PN.Tte
Adriansyah alias AR alias Ardi (DPO), Junior Djoko Satrio alias Djoko (yang diajukan dalam berkas perkara terpisah), Nurrizkiah Juliyanty alias Anti (yang diajukan dalam berkas perkara terpisah), yakni Ruslan Sidayat, Hairunisa Koja, Sutanty Sidayat, Asrulsani, Rosmala Katang, Ekawati Andi Mahmud, Sulastri H. Abdul Latif, Megawati Amra, Suriadi Dan Muhammad Janwar, namun berdasarkan data pada Kepolisian Daerah Maluku Utara hingga saat ini kasus-kasus tersebut masih dalam proses penyidikan sedangkan terhadap Adriansyah saat ini statusnya masih dalam daftar pencarian orang (DPO).

Kemudian untuk pelaku atas nama Astrid Fitrianti, Dedi dan Siti Rahmatia Haras serta putusan atas nama Suhesti. Dalam putusan nama Astrid Fitrianti yang didakwa secara bersamasama dengan Hastuti Alias Cili, Maswita, Sugiarti R.A. Hataul Alias Naila, Siti Rahayu Falila Alias Ayu Falila dan Dewi Irawati Alias Ayu Pakaya, namun hingga saat ini Kepolisian baru memproses Hastuti dan Imeldawati Darjan itupun karena adanya laporan dari Naufal Hasan, dkk, bukan merupakan tindak lanjut dari adanya putusan pengadilan. Sedangkan pelaku lainnya yakni Maswita, Sugiarti R.A. Hataul Alias Naila, Siti Rahayu Falila Alias Ayu Falila dan Dewi Irawati Alias Ayu Pakaya hingga saat ini belum ada kejelasan akan proses hukumnya, karena hingga saat ini belam dilakukan penyidikan atas para pelaku yang didakwa secara bersama-sama denga Astrid Fitrianti sebagaimana disebutkan dalam Putusan Pengadilan Negeri Ternate. Begitu pula dengan dalam putusan Suhesti yang menyebutkan masih ada pelaku lain yakni Onco Ambu yang juga seharusnya dimintai pertanggungjawaban, namun hingga saat ini belum juga ada kejelasan terkait dengan proses hukum terhadap Onco Ambu tersebut.

Berdasarkan apa yang telah diuraikan diatas penulis kemudian melakukan wawancara dengan salah seorang penyidik ${ }^{20}$ pada Direktorat Kriminal Khusus Polda Maluku Utara yang mengatakan bahwa, masih terdapat pelaku yang secara bersama-sama dengan pelaku lainnya yang sudah lebih dulu kita limpahkan berkasnya ke Kejaksaan, namun para pelaku lain ini masih dalam tahap penyidikan dengan mengumpulkan alat-alat bukti agar dapat menjerat mereka. Berkas perkaranya memang kita tidak limpahkan secara bersama-sama karena keterbatasan jumlah personil penyidik dalam setiap unit yang melakukan pemeriksaan saksi-saksi, sehingga agak sedikit menghambat dalam proses penyidikan. Selain itu karena banyaknya yang menjdi korban sehingga banyak pula saksi-saksi yang harus diperiksa, dengan keterbatasan jumlah penyidik yang dimiliki oleh pada Direktorat

${ }^{20}$ Wawancara dengan Asdar, Selaku Penyidik Pembantu pada Unit II Fismondev Polda Maluku Utara pada Hari Selasa Tanggal 24 September 2019

http://ejournal.unkhair.ac.id/index.php/humano 403 
Jurnal Penelitian Humano, Vol. 10 No. 1 Edisi Juni 2019

Kriminal Khusus Polda Maluku Utara. Untuk perkara yang berdasarkan putusan pengadilan akan ditindak lanjuti hanya saja pihak penyidik membutuhkan waktu dengan menyelesaikan satu persatu. Meskipun demikian kami selaku penyidik sudah berupaya semaksimal mungkin untuk menuntaskan kasus ini.

Dari keterangan tersebut telah jelas bahwa dalam proses penyidikan tindak pidana penghipunan dana masyarakat dengan modus investasi di Kota Ternate belum dapat berjalan dengan efektif sebagaimana harapan dari para korban disebabkan karena banyaknya pelaku yang mana setiap pelaku memiliki banyak korban sehingga menjadi kendala bagi penyidik dalam melakukan pemeriksaan saksi-saksi, oleh karena jumlah penyidik yang sangat terbatas jumlahnya. Sehingga proses penyidikan pun berjalan lambat, dan tidak ada kepastian hukum baik bagi para pelaku dan terutama bagi para korban yang telah menderika kerugian hingga milyaran rupiah.

b. Penuntutan oleh Kejaksaan

Proses penuntutan tindak pidana penghipunan dana masyarakat dengan modus investasi yang dilakukan oleh Jaksa Penuntut Umum pada Kejaksaan Tinggi Maluku Utara terkesan tebang pilih dan tidak ada konsistensi dalam penetuan besar ringannya sanksi pidana yang dituntutkan kepada para pelaku. Hal demikian tampak dari data hasil penelitian yang menunjukan tuntutan pidana yang diajukan oleh Kejaksaan Tinggi Maluku Utara bervariasi angkanya. Entah apa yang menjadi pertimbangan dari Penunut Umum yang menangani masingmasing perkara tersebut. Terdapat perbedaan jumlah kerugian yang disebabkan oleh masingmasing pelaku, namun untuk Astrid Fitrianti yang jumlah kerugiannya mencapai Rp. 6.618.700.000, dituntut sama dengan Dedi dan Siti Rahmatia Haras yang kerugiannya hanya Rp. 1.186.500.000 yakni 7 (tujuh) Tahun penjara dan denda 10 Milyar rupiah. Sedangkan untuk Suhseti dituntut 8 (delapan) tahun penjara dan denda 10 milyar rupiah padahal kerugiannya hanya Rp. 1.587.000.000, artinya masih jauh lebih seikit dari pada kerugian yang sebabkan oleh Astrid Fitrianti. Dengan demikian terlihat bahwa tuntutan pidana yang diberikan oleh Penuntut Umum Kejaksaan Tinggi Maluku Utara tidak konsisten dan tidak mempertimbangkan besar kecilnya jumlah kerugian yang disakibatkan oleh perbuatan pelaku tindak pidana.

Hasil wawancara dengan salah satu Penutut Umum ${ }^{21}$ yang menangani perkara tindak pidana penghimpunan dana masyarakat dengan modus investasi mengatakan bahwa yang menyebabkan terjadinya perbedaan besar ringannya sanksi pidana dalam tuntutan Penuntut

\footnotetext{
21 Wawancara dengan Mokshin Umalekhoa, Selaku Jaksa penuntut Umum pada Kejaksaan Tinggi Maluku Utara pada Hari Kamis Tanggal 26 September 2019
}

Umum adalah karena sistem penuntutan dalam intenal kejaksaan itu sendiri. Dimana seorang penuntut umum yang akan menuntut terdakwa di persidangan terlebih dahulu mengajukan rencana tuntutan kepada pimpinan, setelah pimpinan menyetujui barulah penuntut umum dapat mengajukan tuntutannya dipersidangan. Namun pada saat pengajuan rencana tuntutan kepada pimpinan yang sertai dengan pertimbanganpertimbangan yang didsarkan pada fakta-fakta hukum yang terungkap dipersidangan, biasanya pimpinanlah yang menentukan besar kecilnya (angka) sanksi pidana dalam rencana tuntutan yang diajukan. Apalagi jika terdapat beberapa pelaku kemudian Penuntut Umum yang menangani juga terdiri dari beberapa orang yang berbeda-beda, sehingga potensi terjadinya perbedaan besaran angka sanksi yang dituntutkan kepada terdakwa akan terjadi. Hal tersebut hanya dapat dihindari jika yang menangani perkara yang sejenis hanya satu orang penuntut umum saja dan sepenuhnya penentuan angka sanksi pidana diserahkan sepenuhnya kepada penuntut umum yang menangani perkara tersebut. Namun kenyataannya tidak seperti itu.

Berdasarkan hasil wawancara diatas, telah diketahui bahwa persoalan bebedanya penerapan besaran angka sanksi pidana yang dituntut oleh penuntut umum disebabkan lebih pada sistem penuntutan dalam internal kejaksaan. Seakanakan tampak tidak adanya kemandirian dari seorang penuntut umum yang menangani suatu perkara untuk mengajukan tuntutan pidana. Padahal yang paling mengetahui tentang faktafakta persidangan adalah penuntut umum yang langsung mengikuti jalannya persidangan. Hal demikian menyebabkan tidak efektifnya pelaksanaan penuntutan dalam penuntutan tindak pidana penghipunan dana masyarakat dengan modus investasi di Kota ternate.

\section{c. Persidangan di Pengadian}

Dari lima perkara tindak pidana penghimpunan dana masyarakat secara ilegal dengan modus investasi yang menjalani proses persidangan. Tiga diantaranya telah mendapatkan putusan dari hakim sedangkan dua diantaranya masih dalam status tahap persidangan. Jika melihat tiga perkara yang telah diputus terdapat perbedaan dan bahkan bisa dibilang terjadi disparitas pemidanaan. Hakim dalam menjatuhkan putusan terlihat tidak konsisten. Astrid Fitrianti yang jumlah kerugiannya mencapai Rp. 6.618.700.000, dituntut sama dengan Dedi dan Siti Rahmatia Haras yang kerugiannya hanya Rp. 1.186.500.000 yakni 7 (tujuh) Tahun penjara dan denda 10 Milyar rupiah kumudian oleh hakim Astris Fitrianti diputus bersalah dan dihukum penjara selama 5 (lima) Tahun dan denda 10 milyar rupiah sedangkan Dedi dan Siti Rahmatia Haras divonis 7 (tujuh) tahun dan denda 10 milyar rupiah mengikuti tuntutan penuntut umum. Kemudian untuk 
Jurnal Penelitian Humano, Vol. 10 No. 1 Edisi Juni 2019

Suhseti dituntut 8 (delapan) tahun penjara dan denda 10 milyar rupiah padahal kerugiannya hanya Rp. 1.587.000.000, oleh hakim diputus bersalah dan dihukum Penjara 5 tahun 6 bulan dan denda 10 Milyar. Melihat fakta tersebut sangat cukup jelas terjadinya disparitas pemidanaan dalam suatu peradilan. Dimana perbuatan yang dilakukan oleh pelaku sama dan bahkan modus operandinya pun mirip hanya saja yang membedakan adalah jumlah kerugian yang diakibatkan oleh pelaku. Idealnya hakim menjatuhkan hukuman sesuai dengan perbuatan dan akibat dari perbuatan terdakwa, sehingga keadilan hukum dapat dirasakan oleh terdakwa.

Hasil wawancara dengan salah satu Hakim $^{22}$ yang memeriksa dan memutus tindak pidana penghimpunan dana masyarakat secara ilegal dengan modus investasi terkait dengan terjadinya disparitas pemidanaan, hakim tersebut mengatakan bahwa dari tiga perkara yang telah diperiksa dan diputus tersebut telah melalui musyawarah dan telah melalui proses pertimbangan hukum sebagaimana dalam prosedur pengambilan putusan. Kemudian dari ketiga putusan tersebut semuanya telah berkekuatan hukum tetap, artinya tidak ada lagi pihak-pihak yang keberatan dengan putusan hakim baik terdakwa maupun Penuntut Umum. Sehingga putusan tersebut telah memenuhi rasa keadilan baik oleh terdakwa maupun korban yang dalam hal ini diwakili oleh negara melalui penuntut umum.

Berdasarkan apa yang telah dikemukakan oleh hakim tersebut diatas, menurut penulis hakim tersebut belum dapat menjelaskan alasan hukum sehingga terjadi disparitas dalam pemidanaan. Kebiasaan hakim yang diwawancarai selalu menyatakan bahwa ketika putusan tersebut telah diterima oleh terdakwa dan penuntut umum maka putusan tersebut sudah memenuhi rasa keadilan para pihak. Oleh karenanya peneliti kemudian melakukan wawancara dengan salah satu nasabah/korban ${ }^{23}$ yang mengatakan bahwa atas putusan hakim tersebut kami selaku korban belum mendapatkan keadilan disebabkan karena para pelaku hanya dijatuhi pidana penjara minimal atau hanya ratarata 5-6 tahun, belum sebanding dengan jumlah kerugaian yang kami derita sebagai korban. Belum lagi tidak ada kejelasan mengenai pengembalian kerugian yag telah kami derita. Bisa saja setelah para pelaku menjalani hukuman dan bebas nanti, para pelaku masih menikmati dana yang telah dihimpung dari kami para korban.

Dari hasil wawancara terhadap hakim dan korban tersebut terdapat dua sisi keadilan yang berbeda yang mana hakim menganggap bahwa

\footnotetext{
${ }^{22}$ Wawancara dengan Sugiannur, Selaku Hakim Pengadilan Negeri Ternate pada Hari Jumat Tanggal 27 September 2019

${ }^{23}$ Wawancara dengan Junaidi, Selaku nasabah/korban CV. Ubay Jaya pada Hari Kamis Tanggal 13 September 2019
}

putusnnya telah adil karena tidak adanya upaya hukum lagi dari penuntut umum sedangkan korban merasa belum ada keadilan sama sekali meskipun para pelaku telah dihukum pidana penjara. Hal ini menunjukkan bahwa penegakan hukum tindak pidana penghimpunan dana masyarakat secara ilegal dengan modus investasi di Kota ternate masih sangat jauh dari kata efektif untuk mengukur mengenai efektifitas penegakan hukum tersebut akan diukur dengan teori sistem hukum dari Lawrence Friedman.

Menurut Lawrence Friedman ${ }^{24}$ berhasil atau tidaknya Penegakan hukum bergantung pada: Substansi Hukum, Struktur Hukum, dan Budaya Hukum. Jika dilihat dari prosesnya, penegakan hukum yang ada diwilayah Polda Maluku Utara, Kejaksaan Tinggi Maluku Utara dan di Pengadilan negeri Ternate meliputi:

1) Substansi Hukum pelaku Tindak Pidana Penghimpunan Dana Masyarakat Secara Ilegal Dengan Modus Investasi dengan modus investasi dijerat dengan UndangUndang Nomor 10 Tahun 1998 tentang Perubahan atas Undang-Undang Nomor 7 Tahun 1992 tentang Perbankan, hanya saja ancaman hukuman dalam UU perbankan tersebut belum dapat memberikan efek jera bagi para pelaku tindak perbankan, sebagaimana dapat kita lihat pada data hasil penelitian terdapat empat orang pelaku dari 3 kasus berbeda yang telah diputus bersalah oleh pengadilan dan dijatuhi pidana penjara, namun tidak membuat pelaku-pelaku lainnya takut atau jera dalam menghimpun dana masyarakat, oleh sebab itu perlu untuk meninjau kembali ancaman hukuman yang ada dalam UU perbankan sehingga dapat menjadi pelajaran bagi orang-orang yang akan menghimpun dana masyarakat. Selain itu perlu adanya ketentuan hukum atau penambahan norma yang mengatur bahwa harta benda para pelaku dapat disita guna membayar kerugian yang diderita oleh para korban. Tidak adanya pengaturan tentang penyitaan harta benda milik pelaku membuat pelaku semakin tidak takut untuk menghimpun dana dari masyarakat secara ilegal.

2) Struktur hukum terkait penanganan tindak pidana penghipunan dana masyarakat secara ilegal dengan modus investasi dalam perkembangannya, upaya penanganan pada tingkat kepolisian Polda Maluku Utara semata-mata dilakukan hanya karena berdasarkan laporan dari masyarakat, belum ada inisiasi dari aparatnya sendiri untuk melakukan penyedikan awal terkait bisnis yang terindikasi kejahatan penipuan bermodus bank gelap. Padahal kepolisan

\footnotetext{
${ }^{24}$ Lawrence Friedman, "American Law", W.W. Norton \& Company, London, 1984, hal. 6.
}

http://ejournal.unkhair.ac.id/index.php/humano 405 
Jurnal Penelitian Humano, Vol. 10 No. 1 Edisi Juni 2019

sedari awal sudah mengetahui telah terjadi praktik penghimpunan dana secara ilegal, namun tidak ada upaya pencegahan yang dilakukan oleh kepolisian, nanti setelah terjadi gejolak dimasyarakat barulah kepolisain mengambil langkah penegakan hukum. Kegiatan menghimpun dana masyarakat yang dilakukan oleh para pelaku sudah diketahui oleh kepolisian, bahkan banyak anggota kelpolisan yang menjadi nasabah dan bahkan menjadi korban sehingga sangat sulit untuk melakukan pencegahan sebab anggota kepolisian yang terlibat sebagai nasabah secara tidak langsung memberikan ruang bagi pelaku dan turut meyakinkan masyarakat atau nasabah lainnya untuk ikut menginvestasikan uangnya pada pelaku Tindak Pidana Penghimpunan Dana Masyarakat Secara Ilegal Dengan Modus Investasi . Struktur hukum lain yang berperan adalah Jaksa Penuntut Umum dan Hakim yang menerapkan UU perbankan dalam tuntutan pidana maupun putusannya. Ternyata Jaksa Penuntut Umum dan Hakim, belum maksimal dalam menerapkan hukum sebagaimana dalam tuntutan dan puusannya yang terkesan setangah hati dalam menjatuhkan pidana bagi para pelaku tindak pidana penghipunan dana masyarakat secara ilegal dengan modus investasi, jika dibangdingkan dengan kerugian yang di derita para korban.

3) Budaya masyarakat Ternate atau Maluku Utara yang pada umumnya ingin cepat kaya tanpa perlu bekerja keras inilah yang memberikan peluang bagi pelaku untuk menghimpun dana masyarakat secara ilegal hanya dengan iming-iming keuntungan yang berlipat ganda tanpa berfikir panjang akibat yang akan terjadi dikemudian hari. Masyarakat dengan mudahnya terpedaya dengan bujuk rayu dari para pelaku sehingga tidak lagi peduli apakah perusahaan yang digunakan oleh pelaku tersebut memiliki ijin atau tidak. Pola berfikir masyarakat inilah yang harus diubah, dimana masyarakat tidak boleh cepat percaya hanya dengan imingiming keuntungan yang berlipat.

Teori Fiedman tersebut dapat dijadikan patokan dalam mengukur proses penegakan hukum di Indonesia. Polisi adalah bagian dari struktur bersama dengan organ jaksa dan hakim. Interaksi antar komponen pengabdi hukum ini menentukan struktur hukum. Walaupun demikian, tegaknya hukum tidak hanya ditentukan oleh kokohnya struktur, tetapi juga terkait dengan kultur hukum di dalam masyarakat. Hingga kini ketiga unsur sebagaimana dikatakan oleh Friedman belum dapat terlaksana dengan baik, baik dalam substansi hukum, struktur hukum, dan budaya hukum yang terkait dengan maraknya tindak pidana penghipunan dana masyarakat dengan modus investasi di Kota Ternate.

\section{Simpulan}

Penelitian memunculkan kesimpulan bahwa faktor penyebab masyarakat Kota Ternate banyak yang menjadi korban tindak pidana penghimpunan dana masyarakat secara ilegal dengan modus investasi adalah karena faktor ekonomi dimana masyarakat ingin mendapatkan keuntutnagn yang berlipat tanpa memikirkan akibat yang akan terjadi dikemudian hari, faktor lingkungan dimana masyarakat hanya melihat para nasabah lain disekitar mereka adalah orangorang yang memiliki strata pekerjaan dan pendidikan yang baik sehingga masyaraat lainnya ikut yakin dengan kegiatan penghimpunan dana ilegal tersebut dan faktor penerapan hukum terhadap pelaku yang selama ini belum maksimal dan belum dapat memberikan efek jera bagi para pelaku lainnya dengan beranggapa bahwa jika ia melakukan tindak pidana tersebut hanya dihukum beberapa tahun dan setelah bebas masih dapat menikmati hasil dari kejahatannya.

Penegakan hukum tindak pidana penghimpunan dana masyarakat secara ilegal dengan modus investasi di Kota Ternate belum bejalan secara efektif, hal mana pada proses penyidikan masih terdapat banyak pelaku lain yang belum di proses hingga saat ini, selain itu pada tahap penuntutan dan putusan pengadilan, nampak jelas belaum adanya keseriusan oleh para penuntut umum maupun hakim untuk menerapkan hukuman maksimal bagi para pelaku agar dapat meberikan rasa keadilan bagi para nasabah yang menjadi korban serta dapat menjadi pelajaran bagi pelaku lain sehingga takut dan jera untuk melakukan tindak pidana penghimpunan dana masyarakat secara ilegal dengan modus investasi.

\section{DAFTAR PUSTAKA}

Arsil, Menjerat Investasi Bodong dengan Tindak Pidana Penghimpunan Dana Masyarakat Secara Ilegal Dengan Modus Investasi, (Jakarta: Lembaga Kajian \& Advokasi untuk Indepedensi Peradilan, 2014)

Budi Untung, Buku Cerdas Investasi (Yogyakarta: C.V Andi Offset, 2011)

Hermansyah, Hukum Perbankan Nasional Indonesia, (Jakarta: Kencana Prenada Media Group, 2005)

Kasmir, Bank dan Lembaga Keuangan lainnya, (Jakarta: PT. Raja Grafindo Persada, 2011)

Lawrence Friedman, "American Law", W.W. Norton \& Company, (London, 1984)

Wijdinarto, Hukum dan Ketentuan Perbankan Di Indonesia, (Jakarta: PT. Pustaka Utama Grafiti, Edisi II Cet-1, 2003)

http://sikapiuangmu.ojk.go.id/id/article/128, diakses tanggal 18 Maret 2019

http;//kbbi.web/investasi, diakses tanggal 18 Maret 2019 